have made it possible to determine the characteristics of sound-absorbing materials. The information obtained has enabled the Section to assist Australian firms in the design and manufacture of acoustic tiles and other sound-absorbing materials (Industrial Research News, 19 ; January 1960). In offices, halls and houses extensive use is made of acoustic tiles. These are relatively costly, but have substantial advantages over most other sound absorbers in both appearance and performance. A typical tile consists essentially of a perforated facing of metal or plaster and behind this a blanket of fibrous material, such as mineral wool. In Australia, tiles of this kind, with plaster facings, have become well known and are used to a greater extent than in most countries. With the growing demand, the number of firms producing acoustic tiles has increased considerably in the past few years and the Division has received many inquiries concerning their design. Dr. W. K. Lippert and Mr. W. Davern have been concerned both with research on the basic characteristies of sound-absorbing materials and with tests on products submitted by manufacturers.

\section{Snow Loads and Roof Designs}

Is Canada, the heaviest load for which the roof of a building must normally be designed is the load imposed by snow. The magnitude of the design snowload is thus of considerable importance. It must be high enough to reduce the probability of failure to an acceptable level, but not so high as to result in unreasonable construction costs. Snow loads to be expected in different locations across Canada are given in the National Building Code. These loads are based directly on measurements of maximum ground snow depths over a number of years and are generally considered to meet the requirements of safety. Appreciating the influence of design snow-loads on the cost of construction, the National Research Council Division of Building Research decided to undertake a study of the actual accumulations of snow, ice and rain on roofs as well as on adjacent ground. It was realized that this study must be carried out for a number of years and take into account the whole of Canada. Before embarking on this project, a pilot survey was conducted during the 1956-57 winter. Its results showed that a countrywide survey of actual snow loads on roofs would yield useful information, and that the proposed method and apparatus used would, with a few changes, be suitable for the full survey. More detailed investigations have since been carried out in successive winters, each time increasing the number of locations. A more detailed report of these investigations is to be found in the February issue of Discovery.

\section{Organic Acid Synthesis in Tomato Roots}

IN studies of metabolism in tomato roots, J. van Die has ascertained that carboxylic-and amino-acids are synthesized in the roots and translocated to aerial regions of the plant (Koninkl. Nederl. Akad. Wetens., Proc. C, 62, No. 5, 504; 1959). In experiments in which potassium bicarbonate ${ }^{14} \mathrm{C}$ was supplied to the roots of plants in sand culture, he found that a few minutes after supplying the tracer to the roots, labelled organic compounds could be detected in the bleeding sap. After about $15 \mathrm{~min}$. the secretion of active compounds reached its maximal rate, which was maintained for several hours. Analyses of the bleeding sap showed that most of the activity was present in the organic acid fraction, with malic acid as main constituent, followed by citric acid and a number of still unidentified acids. About 15 per cent of the activity was localized in amino-acids, and a small amount in $\alpha$-ketoglutaric aeid. In the roots the largest part of the activity was found in the organic acids and $\alpha$-ketoglutaric acid, while only small amounts of active amino-acids were present. About 10 per cent of the activity of the roots was localized in proteins.

\section{Geological Society of London}

At the annual general meeting of the Society, held at Burlington House on April 27, the officers and Council for the ensuing year were elected, as follows : President, Prof. S. E. Hollingworth; Vice-Presidents, Mr. A. J. Butler, Mr. T. C. Nicholas, Sir William Pugh, Dr. C. J. Stubblefield; Secretaries, Mr. J. M. Edmonds, Dr. P. A. Sabine ; Foreign Secretary, Prof. O. T. Jones; and Treasurer, Mr. P. Evans. Council Members, Prof. J. G. C. Anderson, Dr. H. W. Ball, Prof. O. M. B. Bulman, Mr. A. J. Butler, Prof. K. C. Dunham, Mr. J. M. Edmonds, Mr. P. Evans, Prof. T. N. George, Prof. W. D. Gill, Dr. D. R. Grantham, Prof. S. E. Hollingworth, Dr. R. G. S. Hudson, Prof. O. T. Jones, Prof. B. C. King, Dr. W. S. MeKerrow, Mr. T. C. Nicholas, Sir William Pugh, Dr. Dorothy Rayner, Dr. P. A. Sabine, Prof. R. M. Shackleton, Dr. C. J. Stubblefield, Prof. J. Sutton, and Prof. P. C. Sylvester-Bradley.

\section{Seventh Commonwealth Entomological Conference}

THE seventh Commonwealth Entomological Conference will be held in London during July 7-16. delegates to it being nominated by the Governments of the various countries of the Commonwealth, including many of the Colonial Territories. The proceedings of the Conference will include a number of open meetings, to be held in the Memorial Hall of the Royal Geographical Society (Exhibition Road entrance), South Kensington, London, S.W.7, on July $7,8,11,12$ and 14, and these will be open to all entomologists and others who may be interested, whose participation in the discussions will be welcomed. At each session a subject of wide interest to economic entomologists will be introduced by one or more invited speakers. The subjects are as follows : recent developments in insecticides for crop protection; problems of applying insecticides; hazards and precautions associated with the use of pesticides; research on stored-products pests and their control; biological control of insects and weeds; insect attack in relation to the physical characters and physiological state of the plant ; investigations on timber-boring beetles ; termite control in afforestation projects and constructional timbers; pathogenic organisms for the control of insect pests : current trends in the study and control of tsetse flies and of locusts; studies of dispersal of insects in relation to their control ; developments in the study of plant viruses and their vectors ; the link between research and its application in the field of plant protection. Programmes giving full details will be available about four weeks before the Conference from the Director, Commonwealth Institute of Entomology, 56 Queen's Gate, London, S.W.7.

University News :

Cambridge

Matriculation requirements are to be modified. Each candidate will be required to hold the General 